\title{
Competition on the Georgia Education Marketplace
}

\author{
Archil Gagnidze $^{1} \&$ Shorena Maglakelidze ${ }^{1}$ \\ ${ }^{1}$ Faculty of Arts and Sciences, Ilia State University, Tbilisi, Georgia \\ Correspondence: Archil Gagnidze, Faculty of Arts and Sciences, Ilia State University, Tbilisi, Georgia. Email: \\ archil.gagnidze@iliauni.edu.ge
}

Received: January 5, 2016

Accepted: March 1, 2017 Online Published: May 29, 2017

doi:10.5539/ies.v10n6p10

URL: https://doi.org/10.5539/ies.v10n6p10

\begin{abstract}
Georgia implemented a nationwide, full scale school voucher program in 2005. The new voucher plan was designed with the intent to provide equitable distribution and efficient utilization of financial and human resources. By introducing the voucher scheme, the government hoped to promote competition among public as well as private schools to push them operate in a cost-effective way and consequently improve education quality. This study tries to identify the effect of increased competition on the quality of education as perceived by school principals and teachers in Georgia. More specifically, we study to identify if the voucher model, as a result of increased competition, has created an environment that is supportive to students in improving their academic performance. Our results suggest that school principals and teachers do not view competition as a force or stimulation towards better quality teaching and improved students' academic achievement.
\end{abstract}

Keywords: school competition, education voucher, school privatization, Georgia, school choice

\section{Introduction}

Financing public schools by vouchers or, the introduction of other forms of market solution to education have been proposed in the search for more efficient and equitable ways for allocating and distributing public resources (Levin \& Belfield, 2005). Although vouchers may take many different forms by design and scale, the central idea is that governments expand the choice of parents by providing them with publicly funded grants and scholarships that can be applied and redeemed at any public or private school approved by the government. Voucher supporters argue that a choice system introduces a competitive pressure and creates strong incentives for schools to operate in a cost-effective manner to outperform other schools in order to obtain and retain students (Levin \& Belfield, 2005). Conversely, voucher opponents argue that a public-school system is necessary to avoid segregation and foster an educated society. To date, evidence on the effectiveness of school vouchers is mixed and inconclusive. Often, debates over vouchers are guided by political and ideological preferences rather than presenting convincing empirical evidence (Levin \& Belfield, 2005).

Nevertheless, various targeted and open-ended voucher programs have been implemented across the world. New York City, Dayton (Ohio), and Washington, DC voucher programs, Milwaukee Parental Choice, and Florida Opportunity Scholarship represent voucher schemes that are limited to a certain group of population, designed with a specific purpose, mainly in targeting aid to low income families. Another type, nationwide voucher systems, has been introduced in Chile, New Zealand, and Sweden (Wolf et al., 2013; Epple et al., 2015; Myers et al., 2016). These full-scale schemes allow every student to use public vouchers at any public or private school approved by the government. Evidence concerning the effectiveness and equitability of both types (i.e., targeted and general plans) voucher models is mixed and not persuasive. Furthermore, there has been a "cream-skimming" and "peer effect" observed in the Chilean model, when better schools attracted and selected the best students coming from affluent families, while disadvantaging low SES students and perpetuating inequalities in the society (Hsier \& Urqiola, 2003).

Despite the lack of evidence on effectiveness of various voucher models across the world, the Republic of Georgia implemented a nationwide voucher program in 2005 (PADECO, 2007; Herczynski \& Durglishvili, 2011; Janashia, 2016). Similar to other countries, the new voucher plan was designed with the intent to provide equitable distribution and efficient utilization of financial and human resources (Simonia, 2007). By introducing the voucher model, the government hoped to promote competition among public as well as private schools to push schools to operate in a cost-effective way (Herczynski \& Durglishvili, 2011). 
Almost all voucher models are premised on the assumption that the expansion of school choice triggers competition among schools that in turn advances the quality of education, or equivalently, improves productive efficiency (Levin \& Belfield, 2005). The ability to attend a school in neighboring districts with publicly funded vouchers enhances choice, and potentially imposes competitive pressures on other public schools (Hanushek \& Rivkin, 2002). However, it is known that an education market functions "properly" and produces competitive pleasure when two fundamental conditions are met: first, parents have a set of choices among public and private schools within and outside a given district or region; and second: multiple suppliers, schools are present on the market (Levin \& Belfield, 2005).

Most commonly, greater efficiency is defined as producing higher academic achievements (often as measured by test scores) at a lesser cost. However, in the Georgian context, it's very difficult to isolate and capture pure competition affects due to a number of amendments to the model since its inception. The voucher model, as a funding instrument, has been modified at least four times, each time integrating a new criterion for funding allocation to schools. Alternatively, it is possible to gouge whether the Georgian voucher model generates a competitive pressure based on the perception of school principals and teachers. Therefore, the focus of this paper is to assess how competitive pressure is reflected in the decisions of school teachers and principal and whether they perceive competition as a force for better educational outcomes.

This study examines the assumption that market competition improves the quality of education and students' academic performance. In doing so, the study strives to identify the effect of increased competition on the quality of education as perceived by school principals and teachers under the Georgian voucher scheme. Hence, the larger question is whether the Georgian school voucher improves the quality of education and students' academic performance as a result of increased competition. The specific questions that concern educational stakeholders and this study addresses are: do the Georgian voucher model generates competitive pressure? Do school principals view that competition improves the quality of teaching and students' academic performance? Similarly, do teachers perceive that the competition under the current voucher model improves the quality of teaching and academic performance?

The structure of this paper is as follows: the next section contains the definition of production efficiency and reviews some studies on various voucher models. Then it presents a brief review of the Georgian education system. It also describes the structure of the voucher model and discuses freedom of choice and regulations under the model. After that, the data, methods and instruments of data collection employed in the study are detailed and explained. Finally, the results section presents descriptive information and discusses the findings of the study.

\section{School Choice and Competition}

Arguments for increased choice and flexibility for parents and schools are based on the belief that competition increases productive efficiently. Productive efficiency in the education production function is commonly defined as increasing students' academic achievements and attainments with available, limited resources. That is the production of a certain level of education at the lowest possible cost (Levin \& Belfield, 2005). Although evidence suggests that competition improves productive efficiency in general, evidence on the scale of improved quality education is mixed and unclear (Levin \& Belfield, 2005).

The Milwaukee Parental Choice Program was the first voucher program in the United States, introduced in 1990 (Witte, 1998). The program intended to allow poor children to attend nonreligious private schools located in the city. In his non-experimental study, Witte (1998) randomly selected a sample of students from Milwaukee public schools and controlled for their prior academic achievements and background characteristics. Witte (1998) found no consistent differences in math and reading between the voucher and public school (comparison group) students. Using treatment and control groups - a random sample and a group of unsuccessful applicants-Rouse (1998) conducted multiple analyses and arrived at a different conclusion. She reported that attending a private school produced yearly math gains by 0.14 standard deviation, while the gains in reading were no significant.

The Cleveland voucher plan is another long-running voucher program in the United States. All students residing within the Cleveland Metropolitan School District are eligible to apply for the Cleveland Scholarship and Tutoring Program. At the same time, students are free to decide whether to go to a religiously affiliated or nonsectarian school. Rouse (1998) compared two groups: voucher recipient and non-recipient applicants and found a very small impact on the participant students' academic achievement. After three years, the gains of voucher students were negative and statistically significant. After five years, the gains of voucher recipients were lower in math but higher in reading compared to those of non-recipient students; also, results were not statistically significant (Rouse, 1998). 
A report from a relatively new DC Opportunity Scholarship Program revealed no compelling evidence that the participation in the program has led to significant gains in students' academic achievement (Wolf et al., 2008; Wolf et al, 2009, Wolf et al, 2013). The program was adopted by the Congress and allowed families to send their children to private schools with the federal funding. Wolf et al (2008) compared students who were awarded a scholarship to those who applied for a scholarship (control group) but failed to obtain one. After two years, the impacts were statistically insignificant ranging from -0.02 to 0.03 standard deviation in math and from 0.05 to 0.08 standard deviation in reading. After three years, the results have slightly changed, though became statistically significant in readings; for math the achievement remained almost at the same level (Wolf et al., 2009).

Results are mixed and non-conclusive from those studies that use different measures of competition as a predictor. Using data on student performance in mathematics across 173 Kentucky school districts and Herfindahl Index (HI) as a measure of competition Borland and Howson (1995) report a marginally significant (Note 1) relationship between academic achievements and competition. However, even though the result of this study was not highly significant, Couch and Shughart (1996) rebutted the findings and contended that mixing public and private schools together in the same HI index introduces a bias against finding a "competition effect". They argued that because of the American school district assignment policy to enroll a child in another public school requires parents to move their place of residence and therefore, switching from one public school to another is much more difficult and costly than switching from a public to a private school (Couch and Shughart, 1996).

Employing the Herfindahl Index and Grade Level Performance Assessments dataset Marlow (2002) examined the effects of competition on students' academic performance in California. Although he concluded that greater competition improves student performance, the result of the study is somewhat mixed. Specifically, he employed the seemingly unrelated regression model and estimated the effects of competition on students' academic achievement controlling for a series of educational inputs (spending, teacher/student ration etc.). The result showed that 10 out of 18 estimations were not statistically significant (Marlow, 2002). Moreover, when the estimates were significant, they were not consistent across the grades. For example, the results of the study suggested that a one standard deviation decrease in HI was associated with a somewhat substantive increase in eighth grade reading scores (Effect Size $=0.41$ ) while the effect for fourth grade reading scores was moderately weak (Effect Size=0.22). Similarly, the effects of competition were fluctuating across the grades on math and writing (Marlow, 2002).

Zanzig (1997) also examined the effect of competition on students' academic achievement in California, but he constructed the model in a somewhat different fashion. He combined two alternative measures of competition the Herfindahl Index and the number of school districts per county. Specifically, based on the Californian statewide dataset - "Iowa Tests of Educational Development" - he created competitive thresholds for counties to balance and control for the number of school districts within counties (Zanzig, 1997). Therefore, using variation of school districts he found that greater competition improves student achievement, and it takes four school districts to make a completely competitive education market. However, additional competition, or the presence of more than four districts generates no further achievement gains. Translating these findings into the effect size suggests that a one standard deviation increase in number of school districts in a county (where number of school districts is less than 4) is associated with about 0.12 standard deviations increase in $12^{\text {th }}$ grade test scores (Zanzig, 1997). Similarly, a one standard deviation decrease in IH is associated with somewhat strong increase in students' test scores.

Evidence for improved educational attainment (measured by drop-out and graduation rates) as a result of competition is also mixed and not conclusive. For instance, Marolow (1997) found that states with more districts and more schools had lower drop-out rates (Levin \& Belfield, 2005). In regard with graduation rates, Dee (1998) concluded that private school student numbers increase graduation rates (Levin \& Belfield, 2005), thus the higher enrollment in private schools the higher graduation rate across the districts. In contrast, using the same sample Sander (1999) found no statistically significant effect on graduation rate (Levin \& Belfield, 2005).

Although evidence from the above reviewed voucher programs provides an essential implication to public policy, their scale and target is limited. It's important to consider evidence from studies assessing full-scale voucher schemes. In 1981, Chile introduced a nationwide school voucher program that allowed all students to use public voucher at any public or private school (McEwan \& Carnoy, 2000). Researchers who studied the Chilean voucher plan have concluded that the students using the voucher at Catholic private schools have done better than the students at public or non-religious private schools (Zimmer \& Bettinger, 2007). However, Catholic private schools were able to use more financial and other resources compared to public schools, and therefore their 
results did not yield a higher level of productive efficiency (McEwan and Carnoy, 2000). In addition, no clear evidence has been revealed that the introduction of competition improved students' performance at the national level. Further, fifteen years of competition produced only modest gains among schools in Santiago, while negatively affected schools in the rest of the county (McEwan 2000, as cited in Ladd \& Fisk 2003).

New Zealand's school choice system represents another example of full scale voucher models. In 1991, New Zealand eliminated geographical school enrollment zones and moved to a market-based system of education. Each school henceforth receives funding on a per-pupil basis financed by the national government. Parents are free to choose their child's school, encouraging competition between schools for students. Unlike the Chilean experience, New Zealand does not have a national testing system and therefore it is impossible to measure the effects of competition on students' achievement as measured by test scores. As an alternative Ladd and Fiske (2003) employed a stratified sample of school teachers and principals to measure their perception of the impact of competition on students learning and other variables. Employing a sample of teachers and principals and the probit regression analysis, Ladd and Fiske (2003) concluded that competition-as perceived by teachers-negatively affected the quality of students learning. As for the principals' perception, the analysis showed neither positive nor negative effects. Specifically, for the principle equation, the coefficients were negative suggesting that competition decreases the quality of learning, but they were not statically significant. Our study largely follows the structure of this research.

\section{The Georgian Context}

Georgia, one of the former Soviet Republics, is located in Southern Caucasus. The county first gained its independence from Russia in 1921, but soon was incorporated into The Union of Soviet Socialist Republics (USSR). After 70 years of Soviet Regime, Georgia finally regained its full independence in 1991. The demise of the Soviet Union in 1991 drove Georgia into social and economic stagnation. Striving to adapt to the new reality, Georgia launched the implementation of structural reforms to transition from a centralized to a market economy. However, this transition was accompanied by unstable political upheavals, increasing poverty, and brain drain. Georgia underwent profound economic, political and social changes after 2003. A new wave of reforms has decreased the state involvement and correspondingly encouraged market mechanisms in steering the public sector.

\subsection{Education System}

Before 2003, the Republic of Georgia operated an inherited, centrally-planned Soviet-style education system. The system was highly corrupt and the personal political power often was a decisive factor in obtaining financial resources (Herczynski, 2001). In order to eradicate corruption, rampant nepotism and improve the system, the government introduced a number of sweeping changes, including the introduction of a full-scale voucher scheme.

In Georgia, formal K12 education is provided by public and private schools. In 2005, all public schools were formed as independent entities to allow financial independence in internal resource allocation. Public schools are run by principals elected by Board of Trustees, composed of parents, teachers, and students themselves. Private schools are legal entities of private law, and receive a general education license from the Ministry of Education and Science. In Georgia, for-profit, nonsectarian schools make up $92 \%$ of the total private schools, while only $8 \%$ of them are religiously affiliated, mainly Christian Orthodox (MoES, 2016). Private schools are required to abide by certain conditions established by the Ministry (Law on General Education, 2004). The Georgian National Educational Curriculum is quite centralized, mandating $75 \%$ of the academic subjects as compulsory for every public as well as private school, leaving only $25 \%$ of elective courses to the discretion of each individual school (MoES, 2016).

The central effort of the extensive education reforms started in 2003 was the introduction of a nationwide school voucher plan, which allowed all students to use public vouchers at any public or private school. At the initial stage, public and private schools were equally funded by the central budget based on the number of enrollees and the standardized base voucher. This arrangement, however, gradually morphed into an approach that favored public schools.

\subsection{Voucher Scheme as an Instrument for School Financing}

Under the initial design (2005-2009) of the voucher model every public and private school annually received the lump sum amount based on their enrollment. The funding distribution formula was very simple across the board: number of enrolled students multiplied by the government defined base voucher constituted the school revenue; this equally applied to public as well as private schools. There were only three distinct levels of the base voucher, 
differentiated based on the geographical location of the school. The funding received through the voucher was appropriated to cover all the recurrent expenditures. Capital outlays remained the responsibility of the central government (MoES, 2005). Obviously, the fixed proportional link between the number of students and the base voucher favored larger schools, making them flexible enough to introduce innovative projects and advance the school environment, while budgets in small schools were mostly absorbed by the payroll and other immediate needs (Simonia, 2007).

This simplistic, single factor funding formula was amended a number of times starting in 2009. First, by integrating an enrolment multiplier, the Ministry decided to limit large schools from receiving excess funding (exceeding their basic recurring expenditures). The multiplier adjusted the base voucher, decreasing in value after a certain threshold of the number of enrolled students. Second, multipliers to factor in inclusive education and schools with multiple campuses were introduced. Lastly, the government defined a separate base voucher for private schools with a lower value, and no additional multipliers applied for them. These were first policy initiatives to signal that more students would no longer mean more revenue, altering the initial unfettered competition on the education marketplace. Looking at the dynamics of the number of private and public school (figure 1), one may assume that at the initial stage the Georgian universal voucher scheme created a marketplace driven by supply, demand, and consumer preference where "good" schools are better off while "inferior" schools go bankrupt (West, 1997).

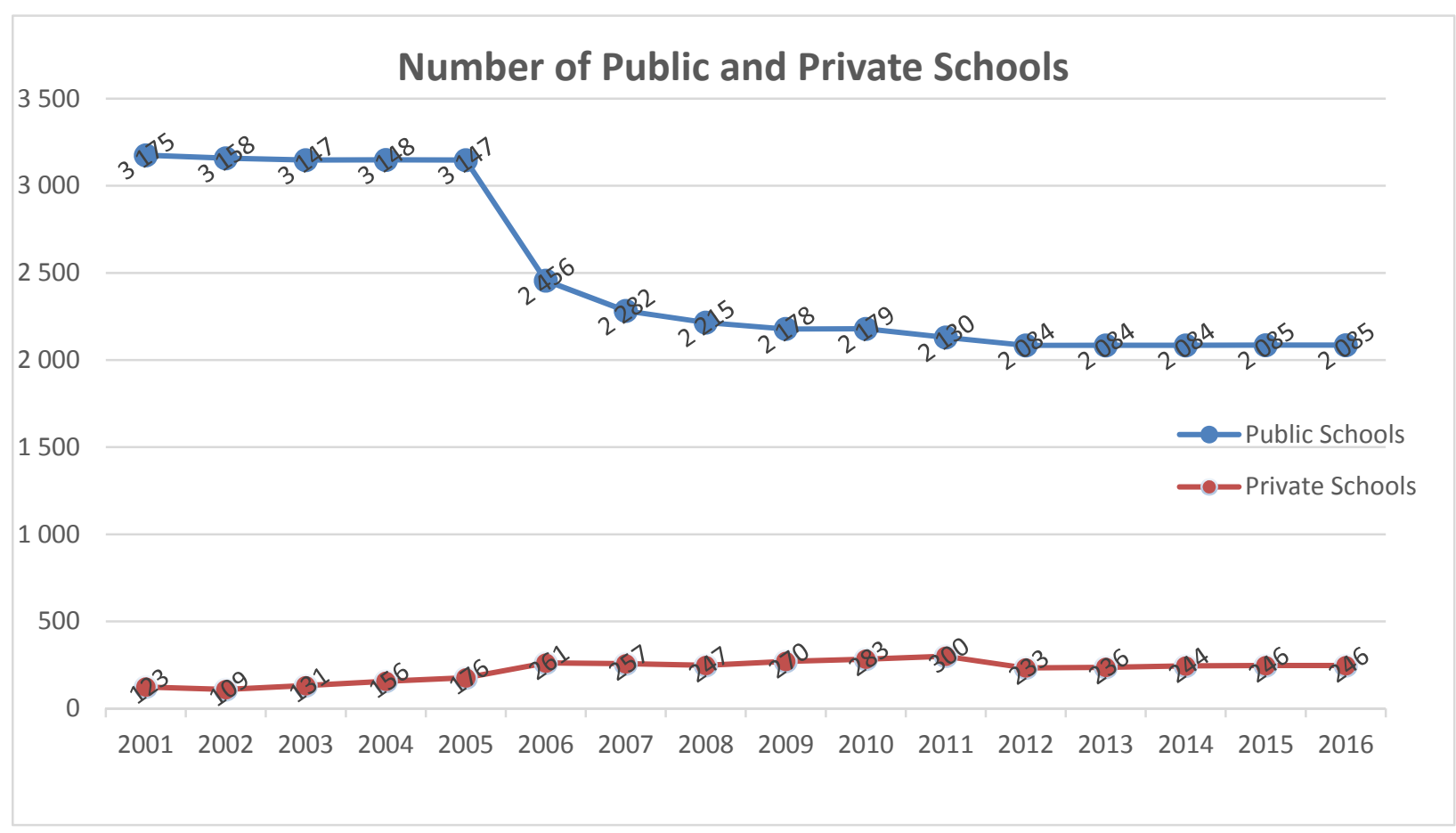

Figure 1. Number of public and private schools in Georgia, 2001-2016

Source: National Statistics Office of Georgia (2016).

In reality, however, the picture is deceptive and the true reason behind the sharp decrease is the "school optimization/consolidation" program implemented by the Ministry. Consolidation of public schools was undertaken extensively in 2004/05 with the aim of promoting the physical, human, and financial resources of schools in the face of the declining population of students in the country (PADECO, 2007). As a result, about 1000 schools were merged with other public schools. The Ministry considered that the number of schools was artificially inflated and through the consolidation it would be lessened to the optimal number (PADECO, 2007). Heczynski (2008) concluded that the Ministry conducted the optimization in preparation for the introduction of a voucher plan, and that by consolidating schools the Ministry had purposely reduced the number of "small" schools. He maintained that the voucher model is not seen as a market tool to identify and isolate weak schools as a result of competition, rather the artificial closure of small schools is a tool for a smoother introduction of the 
voucher (Herczynski, 2008).

\subsection{Choice System}

The Georgian education reform eliminated school assignment restrictions. Before 2003, families were required to send their children to a neighborhood school that was assigned by the Ministry (PADECO, 2007). As in many other cases, by using personal political powers rich and influential families found ways to avoid this regulation and send their children to the school of their choice (Herczynski, 2008). Currently, school choice is expanded and students are free to attend the school they deem best. On the other hand, the number of places available at a particular school is limited and the selection is performed through a designated website on the basis of "first come first served" (MoES, 2016). Private schools are strictly selective, based on the students' academic performance and the ability of a family to cover the tuition fee. Consequently, even if a family selects a public school that meets their need, values, and interest, in the absence of transportation, sending a child to the school is often hard, if not impossible. Similarly, in the presence of "add-ons," private schools are not easily accessible for low income families.

Geographically, Georgia is a mountainous country with many sparsely populated villages and rural areas. Accordingly, about half of all public schools are located in mountainous villages and rural regions. Moreover, there are about 500 villages across the country, each operating only one public school (MoES, 2016). This geographical composition naturally precludes the expansion of school choice. Also, the composition of religious schools bears mentioning. There are over 20 licensed religious schools in Georgia that receive public vouchers, and all of them are Christian Orthodox schools, operating under the supervision of the Patriarchate of Georgia (MoES, 2009). Obviously, the homogenous composition of the religious schools limits freedom of choice of other religious groups residing in Georgia.

Overall, establishing a "full pledged" and fair competitive education marketplace in Georgia has been difficult as many underlining factors influence the process. To some extent, however, mainly in big cities, some degree of competition was created. In the next section, we will present evidence how the increased competition impacts on students' academic achievements and the quality of teaching as perceived by teachers and principals.

\section{Method}

\subsection{Data}

\subsubsection{Site and participant selection}

This analysis is largely based on a survey that was administered in Georgia in 2014 by Ilia State University. The first stage of the site selection was the identification of local schools where school principals would be surveyed. Importantly, to make the principal's sample representative, $10 \%$ of urban, rural and mountainous schools were selected from the list of all public schools. Also, to avoid uneven representation of "big" and "small" schools we took into consideration students' enrollment factor. Thus, the school selection was stratified so that to be proportionally representative of the school distribution by type of school, location and number of students. Finally, based on the stratified sampling, 70 urban 120 rural school and 100 mountainous school principals were selected.

For the teachers' selection, we employed connivance sampling. Therefore, teachers were randomly selected from the schools that were identified for the principal's survey. Thus, based on the connivance sampling we selected 150 urban, 120 rural and 100 mountainous school teachers. We believe that the sample of teachers is quite representative and it allows to capture main trends how the Georgian teachers view the school voucher model in terms of students' academic achievements.

Finally, the selection of both teachers and principals was based on the criterion that they should have had at least 10 years of working experience. This would ensure that they have some knowledge about the old system and thus they are able to judge the positive and negative aspects of both-pre-voucher and voucher systems.

\subsubsection{Instrument}

Structured questionnaires were elaborated separately for principals and teachers. Questionnaires were concise, with short questions phrased in a manner which was easy to understand. The questions were designed to identify teacher's and principal's perception on the voucher model as a market mechanism. Specifically, whether the voucher model generates competitive pressure and how this effects student academic achievement as well as the quality of teaching. 


\subsubsection{Measures}

\subsubsection{Dependent variables}

This study sets out to measure the impact of competition on 1) the quality of teaching and 2) student academic achievement as perceived by teachers and principals. Specifically, teachers and principals were asked to assess how the quality of teaching at their schools has changed since the inception of the voucher model. Similarly, they were asked to evaluate the impact of the voucher model on the students' academic achievement/performance. Responses on both questions were constructed as follows: a) very positive, b) positive, c) no impact, d) negative, e) very negative. To avoid ambiguity and more accurately capture the direction of the impact we collapsed these answers into a polytomous measure with three levels (positive impact $=0$, no impact $=1$, negative impact $=2$ ). Also, we assume that the distances among the three categories are about equal, thus, we did not weight any of these categories.

\subsubsection{Predictors}

The major interest of the study is to evaluate how competition effects academic achievement and teaching quality. Therefore, the measure of competition is the main predictor. To evaluate how school principals and teachers perceive competition, they were asked whether they face some degree of competition. In the questionnaires two possible answers were constructed: a) yes, we face competition, b) no, we don't face competition. We turned these answers into a dichotomous variable with two levels (no competition $=0$, competition $=1$ ).

Ladd and Fiske (2003) raise the issue of validity when competition is measured as perceived by teachers and school principals as it does not explicitly capture the number of schools in a given district. However, they asserted that competition is a rich concept and not always identified by a structural measure such as number of schools. They also argued that competition for students is affected not only by public policies permitting parental choice of schools and by the number of nearby schools, but also by how families evaluate schools. Finally, they concluded that the structural measure of competition such as number of schools do not better reflect a particular competitive environment than the measure based on the perceptions (Ladd \& Fiske, 2003). We consider that the measure of competition as perceived by teachers and principals accurately reflects the competition and competitive pressure, if any, present on the Georgian educational marketplace.

In addition to this measure of competition, we accounted for some confounding variables. First, we considered that school income may influence principals' perception on the relation between competition and students achievement. The principals of "big" schools may think that competition is a position force while the principals of "small" school may have totally opposite opinions. Therefore, we adjusted for the number of students and included it as a continuous variable in the principal's equation. We also considered that family income and years of teaching experience may influence teachers' opinions on the relation between competition and educational outcomes such as students' performance, and teaching quality. Hence, we accounted for teachers' family income and their teaching experience and included both as continuous variables in the teachers' equations.

\subsection{Analytic Approach}

This study seeks possible explanations regarding the extent to which school teachers' and principals' perception on students' academic achievement and the quality of teaching are associated with the competition present on the Georgian educational marketplace. To obtain these associations and draw inferences about the Georgian national school population we conduct the ordinal logistic regression analysis. By conducting the logistic regression analysis we examine how competition impacts on students' academic achievement and teaching quality as perceived by teachers and principals. The ordinal logistic approach is appropriate since our major interest is to capture the direction how the explanatory (competition) variables affect the outcome variables (quality teaching, achievement).

We conduct an initial analysis, Model 1, to obtain the strength of the unadjusted relationship between competition and students' academic achievement as well as between competition and teaching quality as perceived by teachers and principals. We then, in our Model 2, control for the number of students in principals equation, and family income and years of experience in teachers equation. Importantly, the models are constructed separately for village and city schools. The results of our analyses are presented in the findings section of this paper.

\section{Results}

We present both descriptive and analytic results. Descriptive results include a general picture on the presence of competition in cities, villages and mountainous regions as assessed by teachers and principals. Also, in the description section, general views - how the voucher impacts students' academic achievement and teaching 
quality is presented. We then present the results of our regression analyses in two parts. We first discuss the unadjusted relationship between competition and academic achievement as well as between competition and the quality of teaching. Then we display the results of our second regression models which account for the number of students, teacher's family income and years of working experience.

\subsection{Descriptive Data}

Table 1 displays teachers' and principals' evaluations whether their schools face competition. On average, both teachers and principals consider that competition is present among city schools. Over a half of the city school principals and teachers think that their schools face some degree of competition. However, the perception of competition among village school teachers and principals is quite low. Only $32 \%$ of principals and $31 \%$ of teachers believe that they work in a competitive environment. Not surprisingly, competition is almost not present among mountainous schools. As the survey reveals, only $8 \%$ to $10 \%$ of mountainous schools operate in a competitive climate. For this reason, mountainous schools were not considered in our regression analysis.

Table 1. Distribution of the responses about competition as perceived by principals and teachers, by schools' locations

\begin{tabular}{|c|c|c|c|c|c|c|}
\hline \multirow[b]{2}{*}{ Competition } & \multicolumn{2}{|c|}{ City Schools } & \multicolumn{2}{|c|}{ Village Schools } & \multicolumn{2}{|c|}{ Mountainous Schools } \\
\hline & $\begin{array}{c}\text { Principals } \\
n=70\end{array}$ & $\begin{array}{c}\text { Teachers } \\
n=150\end{array}$ & $\begin{array}{c}\text { Principals } \\
n=110\end{array}$ & $\begin{array}{c}\text { Teachers } \\
n=120\end{array}$ & $\begin{array}{c}\text { Principals } \\
n=60\end{array}$ & $\begin{array}{c}\text { Teachers } \\
n=100\end{array}$ \\
\hline Yes $(\%)$ & 52 & 56 & 32 & 31 & 8 & 10 \\
\hline NO (\%) & 48 & 44 & 68 & 69 & 92 & 90 \\
\hline
\end{tabular}

According to our analysis, $37 \%$ of city school principals think that the inception of voucher program positively impacted the quality of teaching. A slightly less number of principals, $32 \%$, recognize the positive impact of the voucher on the students' academic performance. Conversely, a very few city school principals do not attribute the teaching quality and student achievement to the voucher. Importantly, over a half of the principals in cities consider that the voucher had neither positive nor negative impact on the student's academic achievement. Similarly, $46 \%$ of them do not see any impact of the voucher on teaching quality.

As displayed in Table 3, a comparatively higher number of principals in villages think that vouchers adversely affected on both teaching quality and students' achievement. Specifically, $34 \%$ of village school principals referred to the voucher as having a negative impact on teaching quality, and $38 \%$ of them - on student achievement. As expected, only about a one quarter of principals think that the voucher had a positive effect on academic achievement, and $28 \%$ of them see the voucher as having positive impact on teaching quality. Similar to the cities, most of the village principals consider that the voucher had impact on neither academic achievement nor teaching quality.

Table 2. Principals' perception on the impact of competition on the quality of teaching

\begin{tabular}{ccccccc}
\hline & \multicolumn{3}{c}{ City school principals $\mathrm{n}=70$} & \multicolumn{2}{c}{ Village Schools principals $\mathrm{n}=110$} \\
\cline { 2 - 7 } Impact area & $\begin{array}{c}\text { Positive } \\
\text { impact }\end{array}$ & $\begin{array}{c}\text { No } \\
\text { Impact }\end{array}$ & $\begin{array}{c}\text { Negative } \\
\text { impact }\end{array}$ & $\begin{array}{c}\text { Positive } \\
\text { impact }\end{array}$ & $\begin{array}{c}\text { No } \\
\text { Impact }\end{array}$ & $\begin{array}{c}\text { Negative } \\
\text { impact }\end{array}$ \\
\hline $\begin{array}{c}\text { Quality of teaching (\%) } \\
\text { Student's Academic performance } \\
(\%)\end{array}$ & 37 & 46 & 17 & 28 & 38 & 34 \\
\hline
\end{tabular}

Table 3 displays the analysis of the teachers' perception of the voucher's impact on teaching quality and academic achievement. Almost a half of the city teachers believe that students' academic achievement was increased as a result of the voucher program, and $36 \%$ of them agree that the voucher improved the teaching quality. On the other hand, only a one fifth of city teachers think that the voucher worsened both teaching quality and academic achievement. Similar to principals, a fairly high number of city teachers consider that voucher had no impact on teaching quality and academic achievement.

Similar to the city teachers, most of village teachers think that the inception of the vouchers had a positive impact on academic achievement and quality teaching. The survey reveals that $40 \%$ or more teachers believe that the vouchers led to a better student performance and better teaching quality. On the other hand, over $20 \%$ of the 
teachers do not believe the positive impact of the voucher. Finally, nearly $40 \%$ of teachers consider that the voucher model has neither a positive nor a negative impact.

Table 3. Teachers' perception on the impact of competition on students' academic achievement

\begin{tabular}{ccccccc}
\hline & \multicolumn{3}{c}{ City School Teachers $\mathrm{n}=150$} & \multicolumn{3}{c}{ Village Schools Teachers $\mathrm{n}=120$} \\
\cline { 2 - 7 } Impact area & Positive impact & No Impact & Negative impact & Positive impact & No Impact & Negative impact \\
\hline $\begin{array}{c}\text { Quality of teaching } \\
\text { Student's }\end{array}$ & 36 & 42 & 22 & 40 & 37 & 23 \\
$\begin{array}{c}\text { Academic } \\
\text { performance }\end{array}$ & 48 & 31 & 21 & 44 & 34 & 22 \\
\hline
\end{tabular}

\subsection{Analysis}

We begin our analysis by presenting the unadjusted relationship between competition and quality of teaching as perceived by school principals. As displayed in table 4, our logistic regression analysis suggests that there is no significant relationship between competition and quality teaching $(p>0.5)$. Although the coefficients have negative signs suggesting a negative effect of competition on the teaching quality, the coefficients are not statistically significant and the actual effect might be zero due to the error terms. In our Model 2 we introduced the variable of number of students enrolled in the school as a covariate. However, the overall picture has not changed. Again, after controlling for the number of enrollees, the competition (as a predictor for the quality of teaching) variables remain negative, but statistically insignificant. In the next model we will consider associations between competition and students' academic achievement as perceived by school principals.

Table 4. Principals' perception on the impact of competition on the quality of teaching

\begin{tabular}{ccccc}
\hline Characteristics & \multicolumn{2}{c}{ City Schools $(\mathrm{n}=70)$} & \multicolumn{2}{c}{ Village Schools $(\mathrm{n}=110)$} \\
\hline & Model 1 & Model 2 & Model 1 & Model 2 \\
\cline { 2 - 5 } Competition & -.168 & -.227 & -.424 & .439 \\
Number of students & - & -.006 & - & .043 \\
Test of parallel lines $\left(\mathrm{X}^{2}\right)$ & & & & \\
\end{tabular}

${ }^{*} \mathrm{p}<0.05$. Dependent variable: how the quality of teaching has changed since the inception of the voucher model $(0=$ negative, $1=$ no impact; $2=$ positive $)$

As displayed in Table 5, the model 1 explains the unadjusted relationship between competition and students' academic achievement as perceived by principals. Unlike the previous model, now the competition coefficient for city school principals becomes negative and statically significant $(p<0.05)$. Therefore, we can conclude that the Georgian city school principals believe that competition is negatively associated with students' academic achievement. Although it is somewhat difficult to accurately interpret the magnitude of the coefficients in the ordinal logistic regression, our finding can be interpreted as follow: 1 unit increase in the competition variable (from no competition to competition) is associated with the decrease in expected ordered log odds by 0.81 as you move to the next higher category of academic achievement (Note 2). Put differently, city school principals are 0.81 times more likely to believe that the competition has a negative rather than a positive effect on students' academic achievement.

In our second model, we accounted for the number of students enrolled at the school. Importantly, the competition coefficient remains negative and becomes $(\mathrm{p}<0.01)$ larger. To interpret again: after adjusting for enrollment, 1 unit increase in the competition variable is now associated with the decrease in expected ordered log odds by 1.13 as we move to the next higher category of students' achievements. In other words, city school principals are 1.13 times more likely to believe that the competition negatively impacts students' academic achievement. Surprisingly, the competition variable for village school principals is not statistically significant. 
Table 5. Principals' perception on the impact of competition on students' academic achievement

\begin{tabular}{ccccc}
\hline Characteristics & \multicolumn{2}{c}{ City Schools $(\mathrm{n}=70)$} & \multicolumn{2}{c}{ Village Schools $(\mathrm{n}=110)$} \\
\hline & Model 1 & Model 2 & Model 1 & Model 2 \\
\cline { 2 - 5 } Competition & $-.811^{*}$ & $-1.13^{* *}$ & -1.01 & -0.001 \\
Number of students & - & $-.017^{*}$ & - & $-.060^{*}$ \\
Test of parallel lines $\left(\mathrm{X}^{2}\right)$ & & & & .394 \\
\hline
\end{tabular}

${ }^{*} \mathrm{p}<0.05,{ }^{* *} \mathrm{p}<0.01$ Dependent variable: how students achievement improved since the inception of the voucher model $(0=$ negative, $1=$ no impact; $2=$ positive $)$

Our next analysis involves teacher's perceptions of the impact of competition on the quality of teaching. The teacher's equations consistently show that competition negatively affects teaching quality. This finding is almost equally significant across the school location. The first models, in table 6 , describe the unadjusted relationship between competition and teaching quality for village and city schools. In both instances the competition variables are negative and statistically significant. However, we should note that the assumption of parallel lines in the village teachers' equation is violated. Thus, even though the competition variable is significant its actual effect might be different. For this reason, we will not interpret the results for village schools. For city schools, the result suggests that 1 unit increase in the city schools' competition variable (from no competition to competition) is associated with the decrease in expected ordered log odds by 2.59 as you move to the next higher ordered category of quality teaching (Note 3). Yet another way of interpreting this result is: city school teachers are 2.59 times more likely to believe that the competition has a negative rather than a positive effect on students' academic achievement.

Further, in our model 2, we included teacher's family income and years of teaching experience. Notably, holding family income and working experience constant, the competition coefficients remained negative, statistically significant and became larger for both village and city schools. Thus, we can safely conclude that the Georgian teachers believe that competition negatively affects the quality of teaching. Next, we will consider what teachers think about the relation between competition and academic achievement.

Table 6. Teachers' perception on the impact of competition on the quality of teaching

\begin{tabular}{ccccc}
\hline Characteristics & \multicolumn{2}{c}{ City Schools $(\mathrm{n}=150)$} & \multicolumn{2}{c}{ Village Schools $(\mathrm{n}=120)$} \\
\hline & Model 1 & Model 2 & Model 1 & Model 2 \\
\cline { 2 - 5 } Competition & $-2.59^{* * *}$ & $-2.65^{* * *}$ & $-1.83^{* * *}$ & $-1.98^{* * *}$ \\
Family Income & & .000 & -.002 \\
Teaching Experience (years) & & $.143^{* * *}$ & $.167^{* * *}$ \\
Test of parallel lines $\left(\mathrm{X}^{2}\right)$ & .998 & & & 7.13 \\
\hline
\end{tabular}

${ }^{*} \mathrm{p}<0.05 ; * * \mathrm{p}<0.01 ; \mathrm{p}<0.001$ Dependent variable: how the quality of teaching has changed since the inception of the voucher model $(0=$ negative, $1=$ no impact; $2=$ positive $)$

Table 7 displays the relationship between competition and students' academic achievement assessed by school teachers. As before, we first consider the unadjusted relationships between competition and academic achievement and then, in our model 2, we will employ an augmented equation. Similar to the previous results, our first models suggest that there is a significant negative association between the explanatory (competition) and the outcome variable (academic achievement) for both - city and village schools. Because the assumption of parallel lines in the city equation is violated we will not interpret this result. For the village schools, the negative sign and a fairly large value of the competition variable suggest that village teachers strongly believe that competition deteriorates academic achievements.

To better reflect teachers' perceptions and more accurately interpret the results, we accounted for teachers' family income and years of teaching experience in our model 2. Importantly, the competition coefficients almost doubled. These findings suggest that a one unit increase in the competition variable is related with the decrease in expected ordered log odds by 4.91 as you move to the next higher category of academic achievement. Thus, city school teachers are 4.91 times more likely to think that competition has a negative, rather than a positive 
effect on students' academic achievement. The result for the village schools is similarly interpreted.

Table 7. Teachers' perception on the impact of competition on students' academic achievement

\begin{tabular}{|c|c|c|c|c|}
\hline \multirow[t]{2}{*}{ Characteristics } & \multicolumn{2}{|c|}{ City Schools $(n=150)$} & \multicolumn{2}{|c|}{ Village Schools $(n=120)$} \\
\hline & Model 1 & Model 2 & Model 1 & Model 2 \\
\hline Competition & $-2.67 * *$ & $-4.91 * * *$ & $-2.22 * * *$ & $-3.224 * * *$ \\
\hline Family Income & & -.003 & & $-.007^{*}$ \\
\hline Teaching Experience (years) & & $.456^{* * *}$ & & $.298^{* * *}$ \\
\hline Test of parallel lines $\left(\mathrm{X}^{2}\right)$ & $6.29 *$ & 3.58 & 3.27 & 3.94 \\
\hline
\end{tabular}

${ }^{*} \mathrm{p}<0.05,{ }^{* *} \mathrm{p}<0.01,{ }^{* * *} \mathrm{p}<0.001$ Dependent variable: how students achievement improved since the inception of the voucher model $(0=$ negative, $1=$ no impact; $2=$ positive $)$

\section{Conclusions}

Our results provided clear answers to the initial research questions: Teachers and principals perceive that competition among schools does not encourage the creation of an improved teaching and learning environment. This finding is consistent across the school location. Thus, the market based solution to education, and competitive pressure has not been seen positively by school principals and teachers. Our evidence suggests that school principals and teachers do not view competition as a force or stimulus towards better quality teaching and improved students' academic achievement.

By introducing the original full-scale voucher model in 2005, the Georgian government hoped to promote competition among public and private schools that in turn would push schools to operate in a cost-effective way. This theoretical reasoning could not be realized in practice, simply, because of the geographical and demographical factors. The fact that $50 \%$ of all public schools operate in rural and mountainous regions made them "natural monopolists" and the limited number of students in those regions made it impossible to establish competition and competitive pressure. We note that after amending the original model, the government excluded such schools from the competitive voucher scheme.

Finally, considering the movement towards school choice and increased competition across the globe, it seems unrealistic to anticipate that expanding the market and increasing competition among schools would yield gains in school effectiveness.

\section{References}

Borland, M. V., \& Howson, R. M. (1995). Competition, Expenditures, and Student Performance in Mathematics: A Comment on Crouch et al. Public Choice, 87.

Couch, J. F., \& Shughart II, W. F. (1996). Competition, expenditures and student performance: Reply to Borland and Howsen. Public Choice, 87(3), 401-403. https://doi.org/10.1007/BF00118657

Department of Statistics under Ministry of Economic Development of Georgia, (2007). Statistical Yearbook of Georgia. National Statistics Office of Georgia (2016). Retrieved December 7, 2016, from http://www.geostat.ge/index.php?action=page\&p_id=2099\&lang=eng

Epple, D., Romano, R. E., \& Urquiola, M. (2015). School vouchers: A survey of the economics literature (No. w21523). National Bureau of Economic Research. https://doi.org/10.3386/w21523

Fiske, E. B., \& Ladd, H. F. (2003). Does Competition Improve Teaching and Learning? Evidence from New Zealand. Educational Evaluation and Policy Analysis, 25(1), 97-112. https://doi.org/10.3102/01623737025001095

Government of Georgia. (2004). Program for the unified and strong Georgia. Retrieved December 3, 2009, from http://www.government.gov.ge/index.php?lang_id=GEO\&sec_id=49

Government of Georgia. (2005). Establishment of the School voucher values.

Hanushek, E. A., \& Rivkin, S. G. (2002). Does Public School Competition Affect Teacher Quality? University of Chicago Press

Herczynski, J. (2002). The Financing of Georgian Education. CASE Network Studies and Analyses No. 240. https://doi.org/10.2139/ssrn.1440260 
Herczynski, J. (2008). Per Student Financing of Education in Transition Countries: Review of Education Finance Reform in Georgia (Unpublished manuscript).

Herczynski, J., \& Durglishvili, S. (2011). School Voucher in Georgia: Implementation of a simple idea in a complex environment. In J. D. Alonso, \& Sánchez (Eds.), Reforming Education Finance in Transition Countries Six Case Studies in Per Capita Financing Systems (pp. 101-132). Washington DC.: World Bank.

Hsier, T. C., \& Urqiola, M. (2003). When schools compete, how they compete? An assessment of Chile's nationwide school voucher program. National bureau of economic research. Working paper 1008.

Janashia, S. (2016). The introduction of per-capita education financing in former USSR countries (Doctoral dissertation, TEACHERS COLLEGE, COLUMBIA UNIVERSITY).

Levin, H. (1994). School finance. In T. Husen, \& N. Postlethwaite (Eds.), International encyclopedia of education, second edition (pp. 5233-5241). Pergamon Press.

Levin, M, H., \& Belfield, C. (2005). Vouches and Public Policy: When Ideology Trumps Evidence. American Journal of Education, 111, 548-563. https://doi.org/10.1086/431183

Levin, M. H., \& Belfield, C. (2005). Privatizing Educational Choice: Consequences for Parents, Schools and Public Policy. Boulder, CO: Paradigm Publishers.

Marlow, M. L. (2002). Spending, School Structure, and Public Education Quality: Evidence from California. Economics of Education Review, 19(1).

McEwan, P. J., \& Carnoy, M. (2000). The Effectiveness and Efficiency of Private Schools in Chile's Voucher System. Educational Evaluation and Policy Analysis, 22(3), 213-239. https://doi.org/10.3102/01623737022003213

Ministry of Education and Science of Georgia. (2004). The Law of Georgia on General Education. Retrieved November 5, 2009, from http://www.mes.gov.ge/index.php?module=legislation\&type=index\&no=\&leg

Ministry of Education and Science of Georgia. (2005). Establishment of Schools of General Education as Legal Entities of Public Law. Retrieved November 7, 2009, from http://mes.gov.ge/index.php? module=legislation\&page $=$ detals\&id $=294$

Ministry of Education and Science of Georgia. (2005). National Curriculum. Retrieved November 5, 2009, from http://ganatleba.org/index.php? $\mathrm{m}=102$

Ministry of Education and Science of Georgia. (2009). The educational digest. Retrieved February 17, 2010, from http://www.mes.gov.ge/uploads/ganatleba\%statist\%20digest.doc

Ministry of Education and Science of Georgia. (2010). Latest News. Retrieved May 2, 2010, from http://www.mes.gov.ge/content.php?id=849\&lang=geo

Myers, J. P., \& Najeeb Shafiq, M. (2016). Educational Vouchers and Social Cohesion. American Journal of Education, 121, 1 .

PADECO Co. Ltd. (2007). Evaluation of the Ilia Chavchavadze Program in Reforming and Strengthening Georgia's Schools.

Psacharopoulos, G. (2006). The Value of Investment in Education: Theory, Evidence and Policy. Journal of Education Finance, 32(2), 113-136.

Rouse, C. E., \& Barrow, L. (2008). School vouchers and Student Achievement: Recent Evidence, Remaining Questions.

Schmidt-Braul, I., \& Kopp, B. (2007). The Education Systems of Europe (Book chapter on eorgia, pp. 284-298). Springer Netherlands.

Simonia, Z. (2007). School Funding System in Georgia (Unpublished manuscript). The World Bank.

UNDP. (1999), Human Development Report Georgia. Retrieved November 5, 2009, from http:/hdr.undp.org/en/reports/global/hdr1999/

West, E. G. (1997). Education Vouchers in Principle and Practice: A Survey. The World Bank Research Observer, 12(1), 83-103. https://doi.org/10.1093/wbro/12.1.83

Witte, J. (1998). The Milwaukee Voucher Experiment. Educational Evaluation and Policy Analysis, 20(4), 229-251. https://doi.org/10.3102/01623737020004229

Wolf, P. et al. (2008). Evaluation of the DC Opportunity Scholarship Programs: Summary of Experimental 
Impacts after Two Years. Washington, D.C.: U.S. Dept. of Education.

Wolf, P. et al. (2009). Evaluation of the DC Opportunity Scholarship Programs: Summary of Experimental Impacts After three Years. Washington, D.C.: U.S. Dept. of Education.

Wolf, P. J., Kisida, B., Gutmann, B., Puma, M., Eissa, N., \& Rizzo, L. (2013). School vouchers and student outcomes: Experimental evidence from Washington, DC. Journal of Policy Analysis and Management, 32(2), 246-270. https://doi.org/10.1002/pam.21691

Zanzig, B. R. (1997). Measuring the Impact of Competition in Local Government Education Markets on the Cognitive Achievement of Students. Economics of Education Review, 16(4). https://doi.org/10.1016/S0272-7757(97)00003-4

Zimmer, R., \& Bettinger, E. P. (2007). Beyond the Rhetoric: Surveying the Evidence on Vouchers and Tax Credits. In Ladd and Fiske, Handbook of Research in Education Finance and Policy (pp. 447-466).

\section{Notes}

Note 1. Significant at $\mathrm{p}<0.08$ level.

Note 2. We have 3 categories: 1) negative impact; 2) no impact; 3) positive impact.

Note 3 . Here, for the quality of teaching we also have 3 categories: 1) positive impact, 2) no impact, 3) negative impact.

\section{Copyrights}

Copyright for this article is retained by the author(s), with first publication rights granted to the journal.

This is an open-access article distributed under the terms and conditions of the Creative Commons Attribution license (http://creativecommons.org/licenses/by/4.0/). 